\title{
Duration of Storage Reduced Erythrocytes Profiles and Plasmodium Viability in Donor Blood
}

This article was published in the following Dove Press journal:

Journal of Blood Medicine

\section{Nelly Al Audhah ${ }^{1,2}$ \\ Eko Suhartono ${ }^{3}$ \\ Teguh Wahju Sardjono 4 \\ Loeki Enggar Fitri iD ${ }^{4}$ \\ 'Doctoral Program of Medical Science, Faculty of Medicine, Universitas Brawijaya, Malang, Indonesia; ${ }^{2}$ Department of Parasitology, Faculty of Medicine, Lambung Mangkurat University, Banjarmasin, Indonesia; ${ }^{3}$ Department of Chemistry/Biochemistry, Faculty of Medicine, Lambung Mangkurat University, Banjarmasin, Indonesia; ${ }^{4}$ Department of Parasitology, Faculty of Medicine, Universitas Brawijaya, Malang, Indonesia}

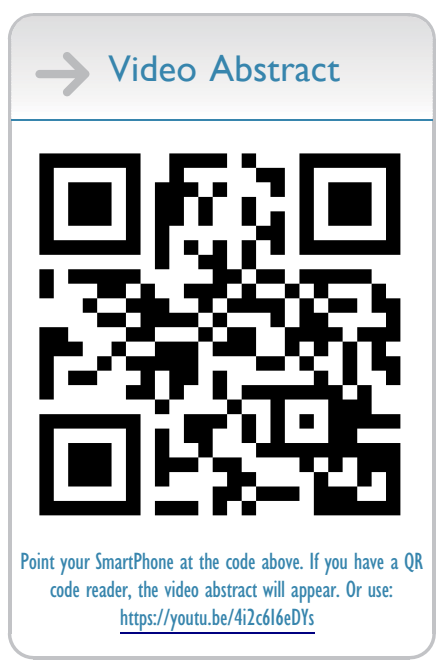

Correspondence: Loeki Enggar Fitri Department of Parasitology, Faculty of Medicine Universitas Brawijaya, Jl. Veteran, Malang, East Java, Indonesia Email lukief@ub.ac.id
Background: Malaria screening for blood derived from any donors prior to transfusions is a standard procedure that should be performed; but, in fact, it is not routinely conducted. In case of the blood is infected with Plasmodium spp., the survival of parasites may be depending on, or even influencing, the profile of red blood cells (RBCs).

Methods: This observational longitudinal study was conducted upon 55 bags of donor blood that randomly selected. Malaria infections were detected using Rapid Diagnostic Test/RDT with thin and thick blood smear confirmation. The changes of Plasmodium spp. viability and RBCs profiles, as well as other hematological parameters, were observed from the results of routine hematological examinations which were performed on days 1,7,14 and 21 of storage. Results: Among 55 blood samples, there were 17 and 38 bags, respectively, positive and negative for malaria, then used for analysis as the case and control groups. There were significant decreasing values $(\mathrm{p}<0.05)$ of all routine blood examination parameters of donor blood, started from days $1,7,14,21$, and 28 . There were no differences in decreasing profiles between those infected and non-infected donor blood ( $>0.05)$. On days 21 and 28 none of the positive samples still contained parasites.

Conclusion: Erythrocytes profiles of donor blood significantly decreased with the duration of storage, but were not influenced by the presence of Plasmodium spp.

Keywords: donor blood, Plasmodium viability, erythrocyte profile, storage

\section{Introduction}

Malaria is one of the leading life-threatening infectious diseases, especially in endemic regions, such as Sub Sahara, South and Central America, and some regions in Asia. Besides the natural cases, transfusion-transmitted malaria (TTM) may commonly occur in an endemic area, through the transfusion of blood from asymptomatic donors. WHO has already recommended following the procedure of blood screening for malaria as well as for HIV, hepatitis, and VDRL, but in fact, those were not routinely conducted, ${ }^{1,2}$ even in Indonesia as well. ${ }^{3}$

The bloods derived from the donors are collected in the bags containing anticoagulant, and if not immediately given to the recipients, they will be stored in certain conditions, such as a temperature of $-4^{\circ} \mathrm{C} .{ }^{4}$ In those specific conditions, the anticoagulant is needed to maintain the viability of blood, together with its containing components, before the transfusion. ${ }^{5}$

In normal condition, the viability of blood especially red blood cells, as long as they are still in the circulation, is around 120 days, before they then are metabolized by the hematopoietic system. But if the RBCs are infected by Plasmodium spp., their viability will be shorter, as they will be damaged by the parasite inside the 
RBCs. The rate of RBC damage will be relevant to the species of Plasmodium, and therefore will influence the RBC profiles also. ${ }^{6}$

There are several hematological parameters routinely used to express the quality of blood components, especially the RBCs profiles; ie, the level of hemoglobin ( $\mathrm{Hb})$, hematocrit (HCT), Mean Corpuscular Volume (MCV), Mean Corpuscular Hemoglobin (MCH), and Mean Corpuscular Hemoglobin Concentration (MCHC). ${ }^{7}$ The quality of the RBCs will also affect the growth of the parasites and indirectly the rate of transfusion-transmitted malaria. For that reason, this study was conducted in order to observe the influence of duration of blood storage prior to transfusion on RBCs profiles, in the blood infected and not infected by Plasmodium spp., as well as the viability of parasites in the infected blood.

\section{Research Design}

This study is an observational longitudinal study using blood from the donation as samples. The bloods were examined for the presence or absence of Plasmodium spp., and divided into two groups Plasmodium spp. (+) and Plasmodium spp. (-). Donor blood had been analyzed for erythrocyte profiles using a hematology analyzer for six parameters. This study was conducted in accordance with the Declaration of Helsinki and approved by the ethics committee of Health Research Faculty of Medicine, Lambung Mangkurat University, through the issuance of an ethical clearance no. 521/KPK-FK UNLAM/EC/X/2017. The donors were informed about the possibility that their blood would not be given to recipients, instead to be used as a research sample, and they understood about it. If they agreed, they must sign an informed consent.

\section{Materials and Methods}

After receiving ethical approval from the Ethics Committee, blood samples were collected at the same time as blood donor activities on Blood Bank, Banjar District and Blood Bank, Tanah Laut District and Blood Bank, from October 2017 to February 2018. We collected 1281 bags of donor blood. Results of malaria screening using RDT and blood smear examinations showed that 17 were positive. As sample size calculation needed 55 samples, we randomly determined 38 malaria negative samples as control with the consideration of matching of sex and age. Prior to the blood donation activity, hemoglobin level, blood pressure examination and a brief interview about donor history were conducted to select donors based on exclusion criteria, such as the age over 60 years, suffering from Diabetes Mellitus, hypertension, asthma, heart disease and congenital blood disorders. The bloods in the bags were taken from donors who were positive and negative for malaria, sent in a cooler box, and then stored at $-4^{\circ} \mathrm{C}$ until they were used for further examinations and analysis, as study and control groups, respectively.

When examining hemoglobin, the residual blood at the fingertips was immediately screened for malaria using blood smear (thin and thick blood smear preparations) and using Rapid Diagnostic Test (Pakar Biomedika Indonesia, catalog number: AUC-01D07) to identify the presence of Plasmodium falciparum histidine-rich protein2 (PfHRP-2) and all species of pan lactate dehydrogenase. The donor blood bags that were used to collect samples contained CPDA-1 anticoagulant (JMS Single Blood Bag $350 \mathrm{~mL}$ Catalog Number 901396401). During the experimental study, the blood was stored at $-4^{\circ} \mathrm{C}$ in the faculty refrigerator and checked daily to ensure the consistency of the temperature. Furthermore, screening for HIV/AIDS, syphilis, and hepatitis was carried out on blood transfusions as a routine screening in accordance with Government Regulation No.7 of 2011. ${ }^{3}$ The changes of erythrocytes (RBCs) profile and other hematological parameters were observed from the results of routine hematological examinations using a hematological analyzer (Rayto Web lab, Type WP-330, catalog no. 42000000AKS-000458665) which were performed on days 1,7,14, and 21 of storage. The viability of Plasmodium spp. was observed using standard Giemsa stain and was determined based on the morphology of the parasite that still contained nucleus and cytoplasm without any form of crisis form.

Erythrocyte profile examination results were tabulated and then calculated for the average and their distribution. Statistical analyses utilized to evaluate the erythrocyte profiles based on the day of observation were the Repeated ANOVA test and post-hoc Paired Wise Comparison test for RBC, HCT and $\mathrm{MCH}$, and Friedman test and post-hoc Wilcoxon test for $\mathrm{Hb}, \mathrm{MCV}$ and $\mathrm{MCHC}$ with a significance level of $\mathrm{p}<0.05$, while erythrocyte profiles based on groups infected with Plasmodium spp. and not infected with Plasmodium spp. were analyzed using the Independent T-test for $\mathrm{RBC}, \mathrm{Hb}, \mathrm{HCT}$, and $\mathrm{MCH}$ and Mann-Whitney test for MCV and MCHC with significance level $\mathrm{p}<0.05$. 


\section{Results}

The characteristics of the research subjects are based on age, gender, education, employment and the blood group classification as mention in Table 1.

The mean value of all parameters of erythrocyte blood profile in all donor blood tended to decrease through the days of observation (Table 2). The statistical results showed that there were significant differences in the profile of RBCs among five different days of observations ( $p=0.000$, using Repeated ANOVA test and Friedman test).

Observations of the presence and the survival of the parasite in the donor blood based on the morphology of Plasmodium spp. were carried out using thin and thick blood smear preparations. Three species of Plasmodium vivax, Plasmodium falciparum, Plasmodium ovale and mixed infections of Plasmodium vivax, Plasmodium falciparum, were identified as shown in Figures 1 and 2.

Until day 14, Plasmodium falciparum, Plasmodium vivax and mix infection still can be detected as immature and mature trophozoite stage with normal morphology containing a regular nucleus and clear cytoplasm without any form of crisis form. Unfortunately, the longer storage makes reduction in the presence of the parasites (Figure 3).

During storage, a decrease in the number of RBCs from donor blood containing Plasmodium spp. was compared to those in the RBCs from donor blood that did not contain Plasmodium spp. There was no significant difference in the results (Independent $T$-test showed the first day, $\mathrm{p}=0.226$; seventh day, $p=0.066$; fourteenth day, $p=0.067$; twenty-first day, $\mathrm{p}=0.050$; twenty-eighth day, $\mathrm{p}=0.375$ ). The mean of RBCs numbers decreased significantly with storage time based on day observation (7th day lower than those at 1st day, 14th day lower than those at 7 th day, 21st day lower than those at 14th day, 28th day lower than those at 21st day, all $\mathrm{p}$ value $=0.000$; Repeated ANOVA test and post-hoc Paired Wise Comparison test). The longer storage led to more erythrocyte lysis, causing more decrease in RBCs number in the two groups. Figure 4 shows there were more than $50 \%$ of RBCs lysis on the 21 st day of observation in both donor blood groups.

The following graph shows a hemoglobin level in serial observations of both groups (Figure 5). There was no significant different about the results (the first day, $p=$

Table I Demographic Characteristics of Research Subjects

\begin{tabular}{|c|c|c|c|c|c|}
\hline \multirow[t]{2}{*}{ Characteristics } & \multirow[t]{2}{*}{ Category } & \multicolumn{2}{|c|}{ Plasmodium spp. $(+)(N=I 7)$} & \multicolumn{2}{|c|}{ Plasmodium spp. (-) $(\mathrm{N}=38)$} \\
\hline & & $\Sigma$ & Percentage & $\Sigma$ & Percentage \\
\hline \multirow[t]{2}{*}{ Sex } & Man & 8 & $47,06 \%$ & 17 & $44,74 \%$ \\
\hline & Women & 9 & $52,94 \%$ & 21 & $55,26 \%$ \\
\hline \multirow[t]{4}{*}{ Age } & $<30$ years & 3 & $17,65 \%$ & 14 & $36,84 \%$ \\
\hline & $30-40$ years & 9 & $52,94 \%$ & 14 & $36,84 \%$ \\
\hline & $4 I-50$ years & 4 & $23,53 \%$ & 4 & $10,53 \%$ \\
\hline & $5 I-60$ years & 1 & $5,88 \%$ & 6 & $15,79 \%$ \\
\hline \multirow[t]{6}{*}{ Employment } & Traders/Seller & 1 & $5,88 \%$ & 3 & $7,89 \%$ \\
\hline & The farmers & II & $64,7 \%$ & 7 & $18,42 \%$ \\
\hline & The miners & 3 & $17,65 \%$ & I & $2,63 \%$ \\
\hline & Company employees & - & & 19 & $50 \%$ \\
\hline & Government employees & - & & 2 & $5,26 \%$ \\
\hline & Not work or students & 2 & $11,76 \%$ & 6 & $15,79 \%$ \\
\hline \multirow[t]{5}{*}{ Education } & No school & 6 & $35,29 \%$ & 2 & $5,26 \%$ \\
\hline & Primary school & 6 & $35,29 \%$ & 5 & $13,16 \%$ \\
\hline & junior high school & 4 & $23,53 \%$ & 13 & $34,21 \%$ \\
\hline & Senior high school & - & & 16 & $42,11 \%$ \\
\hline & University & 1 & $5,88 \%$ & 2 & $5,26 \%$ \\
\hline \multirow[t]{4}{*}{ Blood group } & A & 5 & $29,41 \%$ & 13 & $34,21 \%$ \\
\hline & B & 4 & $23,53 \%$ & 6 & $15,79 \%$ \\
\hline & $A B$ & - & & 3 & $7,89 \%$ \\
\hline & O & 8 & $47,06 \%$ & 15 & $39,47 \%$ \\
\hline
\end{tabular}


Table 2 Erythrocyte Profiles (Mean, Median, Standard Deviation, Minimum-Maximum)

\begin{tabular}{|c|c|c|c|c|c|}
\hline \multirow[t]{2}{*}{ Parameters } & \multirow[t]{2}{*}{ Day of Observation } & \multicolumn{2}{|c|}{ Plasmodium spp. $(+)(\mathrm{N}=\mid 7)$} & \multicolumn{2}{|c|}{ Plasmodium spp. $(-)(\mathrm{N}=38)$} \\
\hline & & $\begin{array}{l}\text { Median } \\
\text { (Minimum-Maximum) }\end{array}$ & Mean \pm SD & $\begin{array}{l}\text { Median } \\
\text { (Minimum-Maximum) }\end{array}$ & Mean \pm SD \\
\hline $\mathrm{RBC}\left(\times 10^{\wedge} 6 / \mathrm{ul}\right)$ & $\begin{array}{l}\text { Ist day } \\
7 \text { th day } \\
\text { 14th day } \\
2 \text { |st day } \\
28 \text { th day }\end{array}$ & $\begin{array}{l}5.31(4.08-6.85) \\
3.63(2.90-5.14) \\
2.27(1.74-3.34) \\
1.24(0.00-2.00) \\
0.00(0.00-1.10)\end{array}$ & $\begin{array}{l}5.35 \pm 0.78^{\mathrm{a}} \\
3.73 \pm 0.59^{\mathrm{b}} \\
2.34 \pm 0.41^{\mathrm{c}} \\
1.29 \pm 0.42^{\mathrm{d}} \\
0.13 \pm 0.35^{\mathrm{e}}\end{array}$ & $\begin{array}{l}4.90(3.86-6.86) \\
3.31(2.62-4.66) \\
2.09(1.64-2.94) \\
1.20(0.00-1.71) \\
0.00(0.00-1.09)\end{array}$ & $\begin{array}{l}5.08 \pm 0.73^{\mathrm{a}} \\
3.41 \pm 0.51^{\mathrm{b}} \\
2.12 \pm 0.33^{\mathrm{c}} \\
1.03 \pm 0.52^{\mathrm{d}} \\
0.42 \pm 0.19^{\mathrm{e}}\end{array}$ \\
\hline $\mathrm{Hb}(\mathrm{g} / \mathrm{dl})$ & $\begin{array}{l}\text { Ist day } \\
7 \text { th day } \\
\text { 14th day } \\
21 \text { st day } \\
28 \text { th day }\end{array}$ & $\begin{array}{l}14.20(11.40-16.40) \\
9.90(8.60-12.30) \\
5.90(5.20-8.00) \\
3.40(2.80-4.80) \\
1.80(0.00-2.60)\end{array}$ & $\begin{array}{l}14.20 \pm 1.09^{\mathrm{a}} \\
9.89 \pm 0.95^{\mathrm{b}} \\
6.20 \pm 0.76^{\mathrm{c}} \\
3.58 \pm 0.55^{\mathrm{d}} \\
1.81 \pm 0.58^{\mathrm{e}}\end{array}$ & $\begin{array}{l}14.30(9.30-16.30) \\
9.60(6.00-11.10) \\
5.90(3.60-7.00) \\
3.40(2.00-4.10) \\
1.80(0.00-2.20)\end{array}$ & $\begin{array}{l}13.80 \pm 1.78^{\mathrm{a}} \\
9.31 \pm 1.24^{\mathrm{b}} \\
5.79 \pm 0.81^{\mathrm{c}} \\
3.31 \pm 0.50^{\mathrm{d}} \\
1.56 \pm 0.66^{\mathrm{e}}\end{array}$ \\
\hline НCT (\%) & $\begin{array}{l}\text { Ist day } \\
7 \text { th day } \\
\text { 14th day } \\
21 \text { st day } \\
28 \text { th day }\end{array}$ & $\begin{array}{l}42.90(36.50-49.60) \\
29.70(24.20-37.20) \\
18.40(14.50-24.20) \\
10.70(8.00-14.50) \\
5.70(4.00-8.00)\end{array}$ & $\begin{array}{l}43.06 \pm 3.35^{\mathrm{a}} \\
30.04 \pm 3.17^{\mathrm{b}} \\
18.85 \pm 2.56^{\mathrm{c}} \\
10.92 \pm 1.86^{\mathrm{d}} \\
5.79 \pm 1.21^{\mathrm{e}}\end{array}$ & $\begin{array}{l}42.75(29.20-51.80) \\
29.05(19.00-35.20) \\
18.05(11.40-22.20) \\
10.40(6.30-12.90) \\
5.50(3.10-6.80)\end{array}$ & $\begin{array}{l}42.31 \pm 5.25^{\mathrm{a}} \\
28.41 \pm 3.68^{\mathrm{b}} \\
17.67 \pm 2.45^{\mathrm{c}} \\
10.11 \pm 1.52^{\mathrm{d}} \\
5.28 \pm 0.88^{\mathrm{e}}\end{array}$ \\
\hline $\mathrm{MCV}(\mathrm{fL})$ & $\begin{array}{l}\text { Ist day } \\
7 \text { th day } \\
\text { 14th day } \\
2 \text { Ist day } \\
28 \text { th day }\end{array}$ & $\begin{array}{l}79.30(56.90-89.10) \\
54.30(42.70-66.00) \\
34.30(25.00-42.90) \\
18.90(13.30-25.70) \\
9.40(6.40-14.20)\end{array}$ & $\begin{array}{l}77.77 \pm 9.00^{\mathrm{a}} \\
54.19 \pm 7.24^{\mathrm{b}} \\
34.03 \pm 5.35^{\mathrm{c}} \\
19.71 \pm 3.67^{\mathrm{d}} \\
10.44 \pm 2.32^{\mathrm{e}}\end{array}$ & $\begin{array}{l}84.00(55.80-89.40) \\
56.4(37.90-60.80) \\
34.65(23.00-38.30) \\
19.95(12.70-22.20) \\
10.55(6.30-11.80)\end{array}$ & $\begin{array}{l}80.74 \pm 9.05^{\mathrm{a}} \\
54.18 \pm 6.19^{\mathrm{b}} \\
33.82 \pm 4.09^{\mathrm{c}} \\
19.35 \pm 2.53^{\mathrm{d}} \\
10.09 \pm 1.48^{\mathrm{e}}\end{array}$ \\
\hline $\mathrm{MCH}(\mathrm{pg})$ & $\begin{array}{l}\text { Ist day } \\
7 \text { th day } \\
\text { 14th day } \\
2 \text { |st day } \\
28 \text { th day }\end{array}$ & $\begin{array}{l}6.70(5.20-8.60) \\
4.70(3.50-5.80) \\
2.90(2.10-3.80) \\
1.70(1.20-2.30) \\
0.90(0.60-1.30)\end{array}$ & $\begin{array}{l}6.69 \pm 1.00^{\mathrm{a}} \\
4.66 \pm 0.70^{\mathrm{b}} \\
2.94 \pm 0.49^{\mathrm{c}} \\
1.71 \pm 0.32^{\mathrm{d}} \\
0.90 \pm 0.21^{\mathrm{e}}\end{array}$ & $\begin{array}{l}7.05(4.50-10.80) \\
4.60(2.90-6.70) \\
2.90(1.70-4.20) \\
1.70(0.90-2.40) \\
0.90(0.50-1.30)\end{array}$ & $\begin{array}{l}7.09 \pm 1.24^{\mathrm{a}} \\
4.68 \pm 0.79^{\mathrm{b}} \\
2.96 \pm 0.55^{\mathrm{c}} \\
1.69 \pm 0.33^{\mathrm{d}} \\
0.89 \pm 0.19^{\mathrm{e}}\end{array}$ \\
\hline$M C H C(g / d l)$ & $\begin{array}{l}\text { Ist day } \\
7 \text { th day } \\
\text { |4th day } \\
2 \text { |st day } \\
28 \text { th day }\end{array}$ & $\begin{array}{l}32.40(27.30-35.40) \\
22.80(17.70-26.60) \\
13.80(10.60-17.30) \\
7.90(5.80-10.40) \\
4.20(2.90-5.70)\end{array}$ & $\begin{array}{l}32.49 \pm 1.84^{\mathrm{a}} \\
22.66 \pm 2.11^{\mathrm{b}} \\
14.24 \pm 1.77^{\mathrm{c}} \\
8.25 \pm 1.32^{\mathrm{d}} \\
4.36 \pm 0.88^{\mathrm{e}}\end{array}$ & $\begin{array}{l}32.85(28.90-45.20) \\
22.25(19.70-30.70) \\
13.95(12.00-19.40) \\
8.10(6.60-11.30) \\
4.30(3.30-6.00)\end{array}$ & $\begin{array}{l}33.51 \pm 2.65^{\mathrm{a}} \\
22.49 \pm 1.87^{\mathrm{b}} \\
13.99 \pm 1.30^{\mathrm{c}} \\
8.00 \pm 0.87^{\mathrm{d}} \\
4.18 \pm 0.53^{\mathrm{e}}\end{array}$ \\
\hline
\end{tabular}

Note: Different notations in superscript letters mean significant difference $(p<0.05)$.

0.402 ; seventh day, $p=0.061$; fourteenth day, $p=0.081$; twenty-first day, $p=0.098$; twenty-eighth day, $p=0.178$; Independent $T$-test). From the observation that was carried out from the first day to the twenty-eighth day of storage, the $\mathrm{Hb}$ levels were significantly different between day observations with all $\mathrm{p}$ value $=0.000$ (Friedman test and Post-hoc Wilcoxon test) both in two groups.

The following graph shows a hematocrit level in serial observation of both groups (Figure 6). Both hematocrit levels from donor blood containing Plasmodium spp. and did not contain Plasmodium spp. decreased over a long period of storage. The trend was similar to that in Figure 4 which shows the decrease of erythrocyte number. Statistical analysis showed there was no difference in the level of hematocrit between the two donor blood groups $(p=>0.05)$. Independent $T$ - test showed the first day, $\mathrm{p}=0.525$; seventh day, $\mathrm{p}=0.105$; fourteenth day, $p=0.118$; twenty-first day, $p=0.127$; twenty-eighth day, $p=0.127$. The longer storage caused more decrease in all of the hematocrit levels in the two groups, which showed there was a difference (all $\mathrm{p}$ value $=0.000$, Repeated ANOVA test and post-hoc Paired Wise Comparison test).

All-day observations of MCV levels from donor blood containing Plasmodium spp. and that not containing Plasmodium spp. were similar and there was no difference 

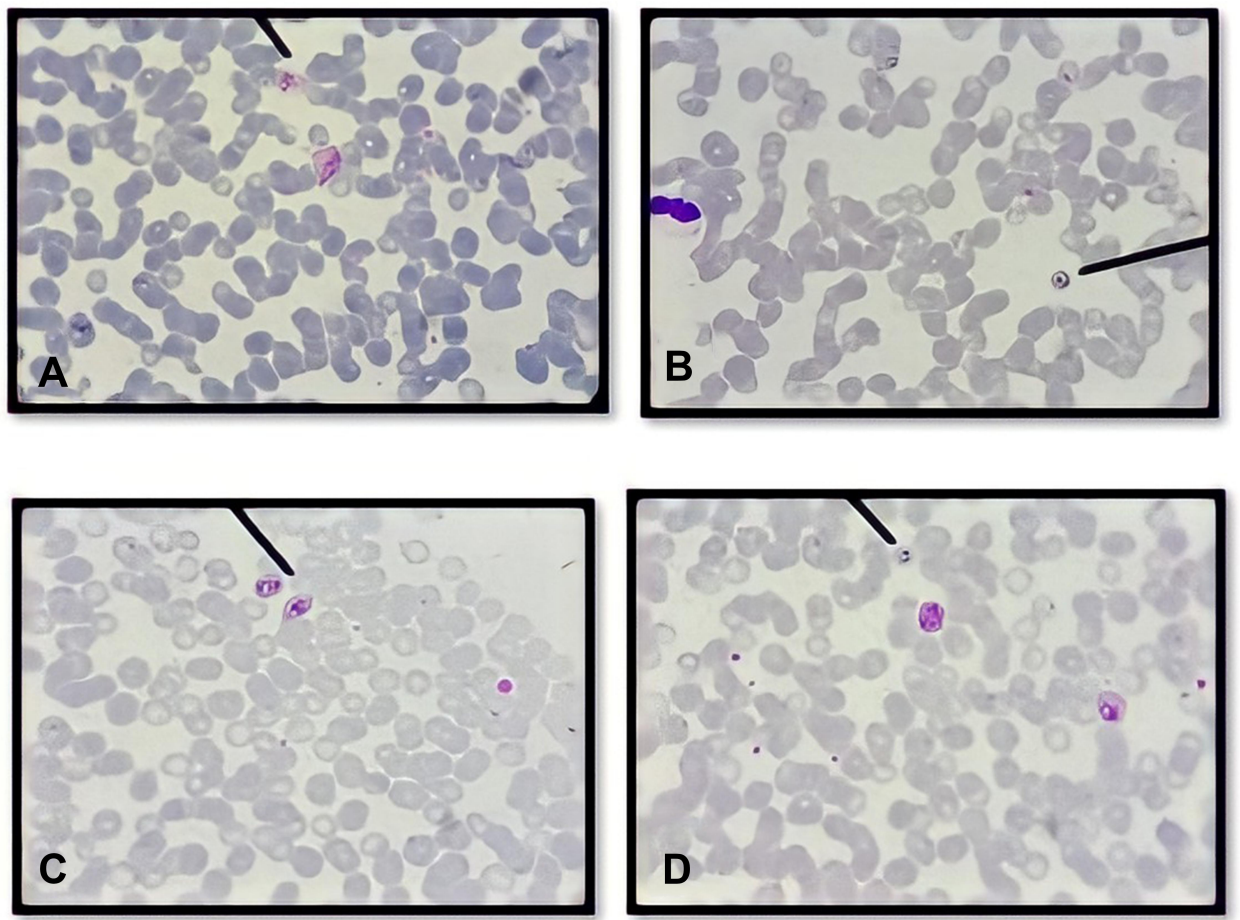

Figure I Species of Plasmodium identified using Giemsa stain on the day of blood collection. (A) Plasmodium vivax; (B) Plasmodium falciparum; (C) Plasmodium ovale; (D) mix infection (Plasmodium falciparum and Plasmodium vivax) were identified in donor blood samples. All the parasites show normal morphology characterized by regular ring form, normal volume of cytoplasm and no halo formation both in trophozoite and gametocyte stages.
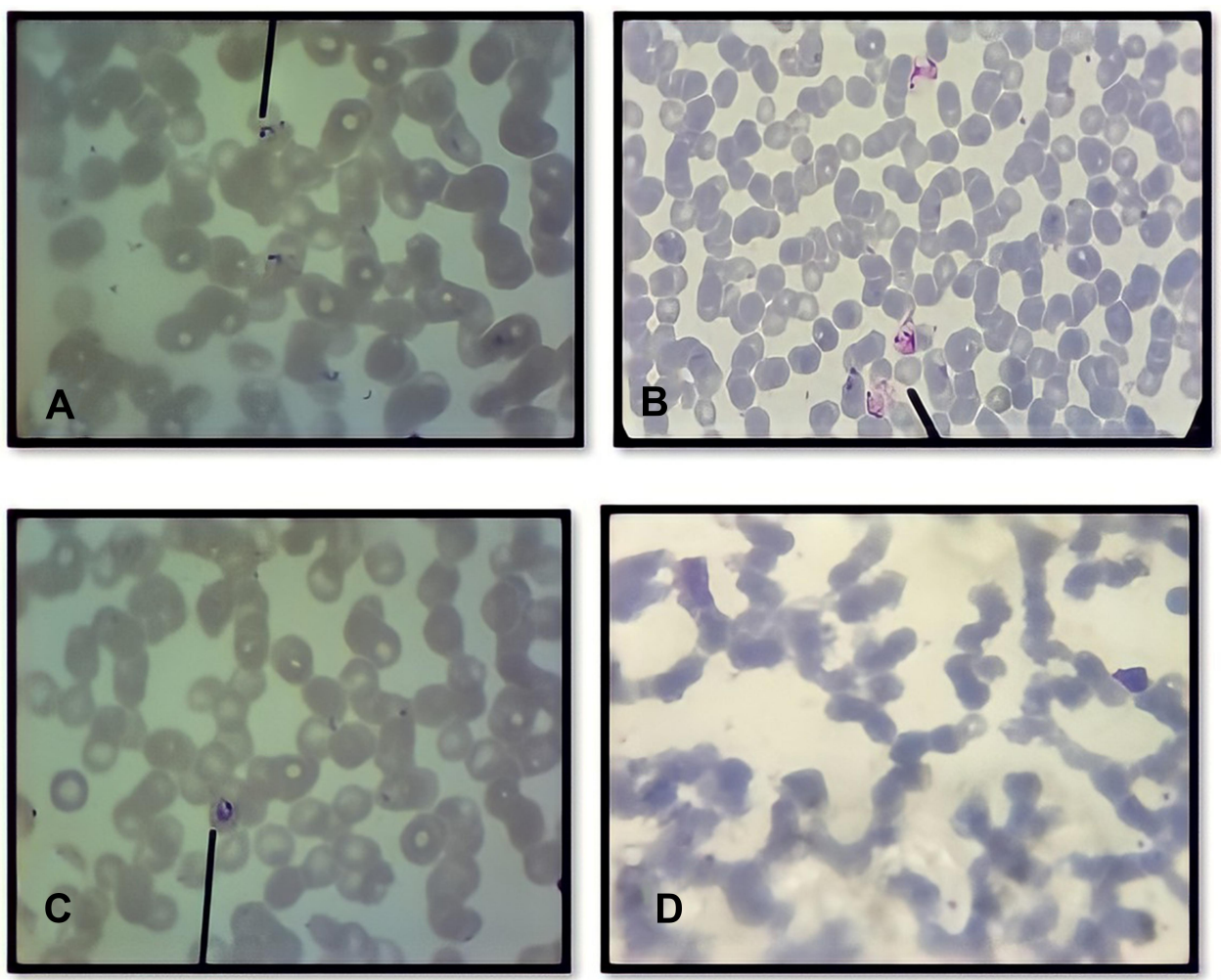

Figure 2 The presence of Plasmodium spp. identified using Giemsa stain on day I, 7 and 14. (A) Several ring form of Plasmodium falciparum characteristic by acole form from day I; (B) Amoeboid form of Plasmodium vivax from day 7; (C) Viable trophozoite of Plasmodium falciparum characteristic by ring form with tick cytoplasm and Maurer's dot from day 14; (D) On day 21 no parasite was found. All the parasites show normal morphology characterized by regular nucleus, normal cytoplasmic volume and no halo formation representing live parasite. 


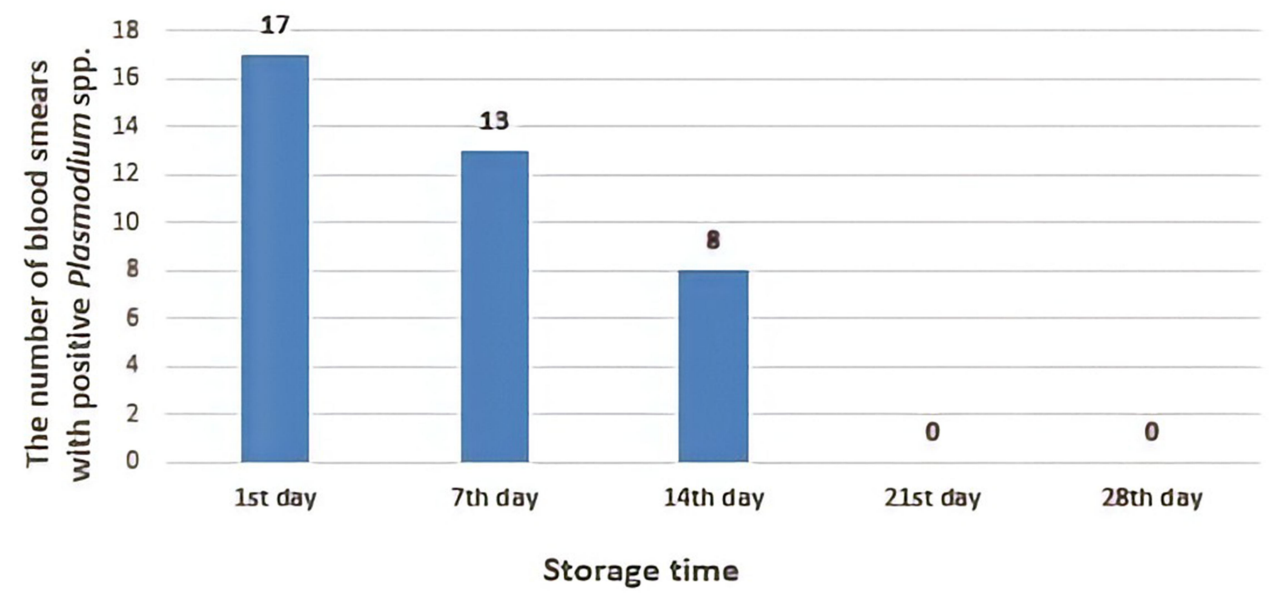

Figure 3 The number of positive samples in blood smears preparations from day I until day 28 . The presence of parasites was reduced through the day observations.

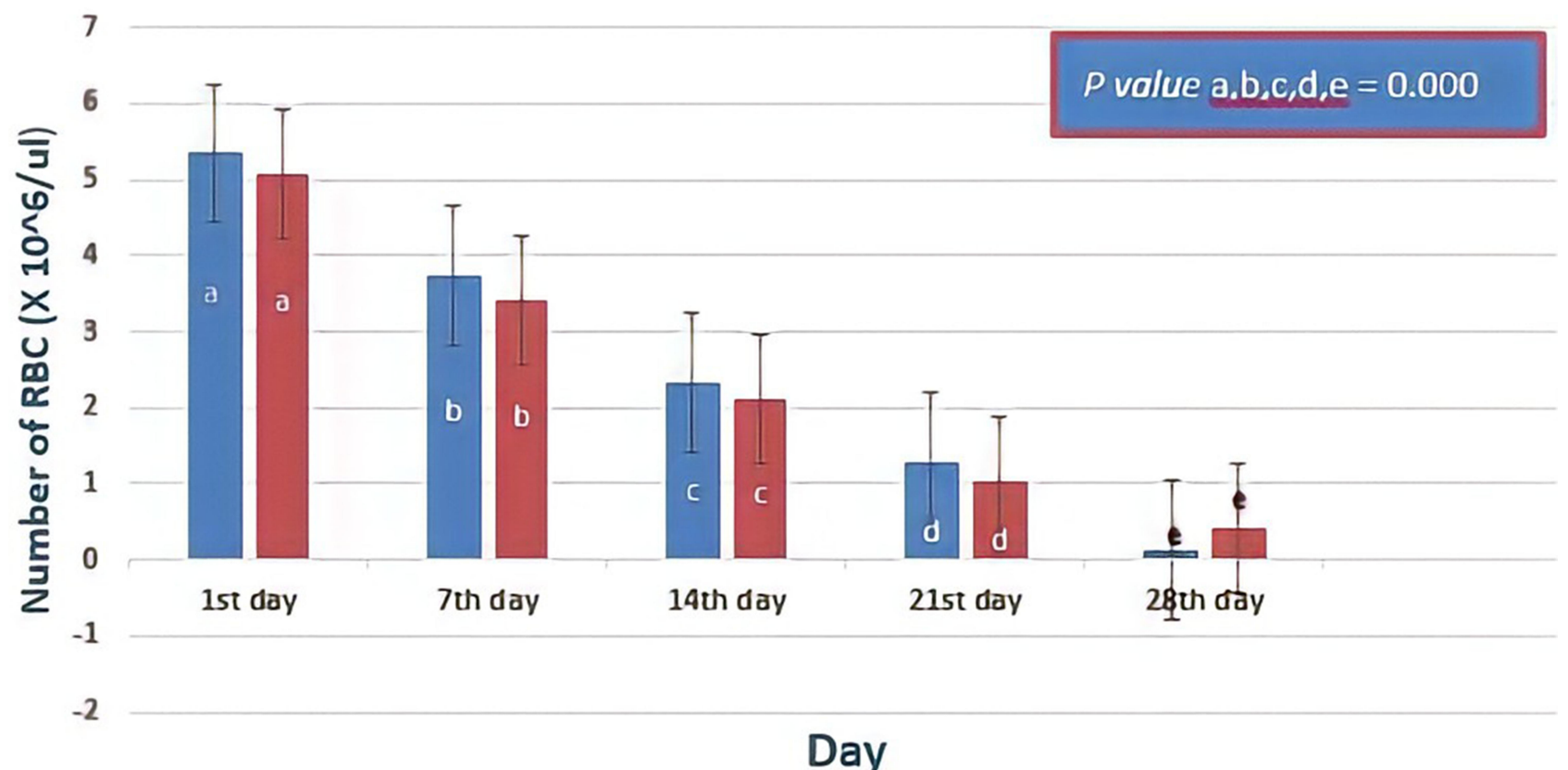

\section{口 Plasmodium spp. (+) घPlasmodium spp. (-)}

Figure 4 The number of red blood cells (RBCs) based on days of observation. In serial day observations, there was no significant difference in the decrease of number of RBCs between donor blood containing Plasmodium spp. and those of donor blood that did not contain Plasmodium spp. ( $\mathrm{p}>0.05$; Independent T-test). However, the means of RBCs number through the day observations were reduced significantly with all $p$ value $=0.000$; Repeated ANOVA test and post-hoc Paired Wise Comparison test) in both groups. Different notations mean significant difference $(p<0.05)$.

between the two groups (Figure 7). Mann-Whitney test showed the p-value from the first day was 0.178 , the seventh day was 0.942 , the fourteenth day was 0.920 , the twenty-first day was 0.792 and, the twenty-eighth day was 0.566 , respectively. However, based on statistics, there was a difference in the average level of MCV in serial observations of both groups (all $\mathrm{p}$ value $=0.000$, Friedman test and post-hoc Wilcoxon test).
Figure 8 shows, from all days of observation, the $\mathrm{MCH}$ of erythrocytes from donor blood containing Plasmodium spp., and those that did not contain Plasmodium spp. were not different. Statistical analysis using Independent $T$-test showed on the first day $\mathrm{p}=0.211$; on seventh day $\mathrm{p}=0.935$, on fourteenth day $\mathrm{p}=0.881$, on twenty-first day $\mathrm{p}=0.814$; and on twenty-eighth day $\mathrm{p}=0.858$. However, based on the Repeated ANOVA test and post-hoc Paired Wise 


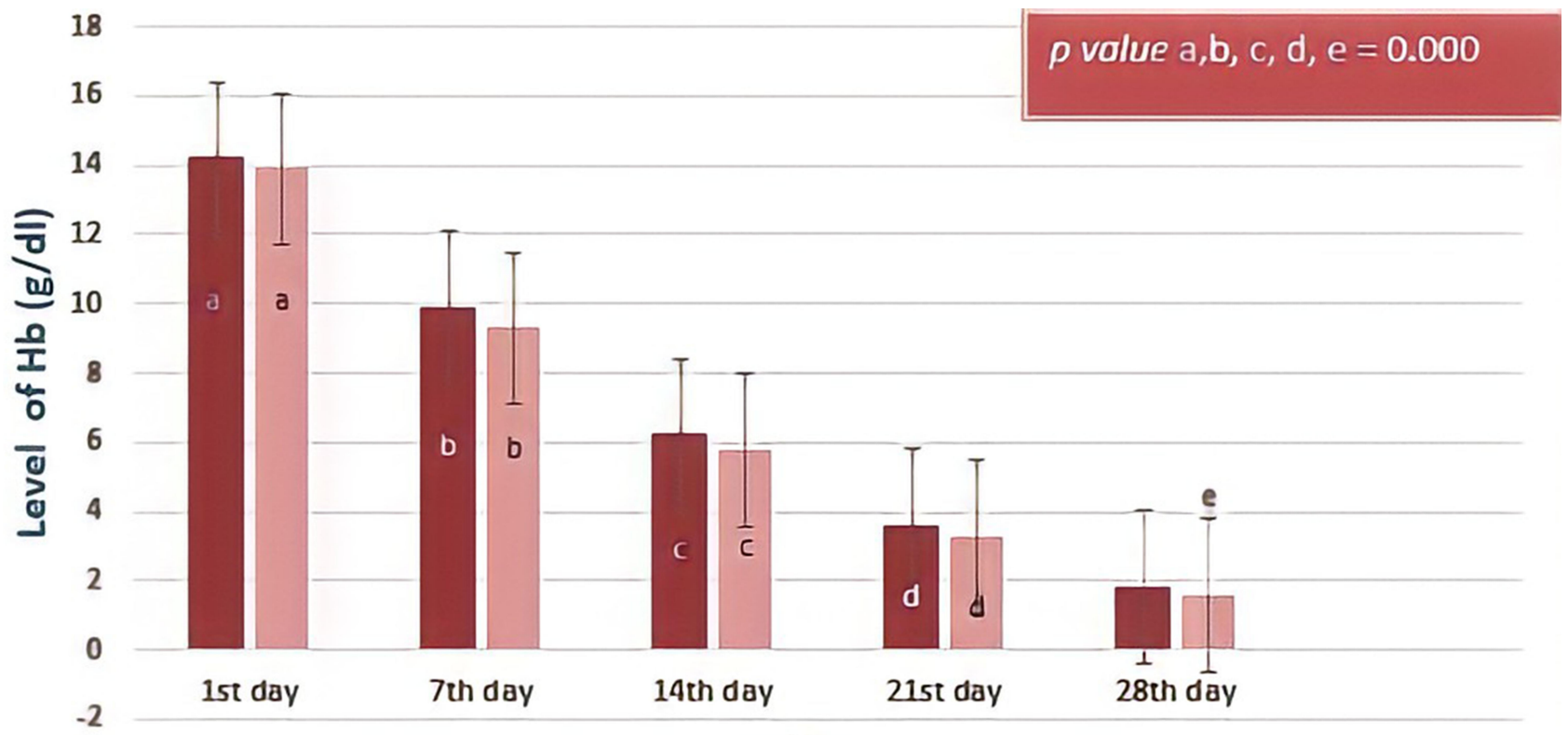

\section{Day}

Plasmodium spp. (+) $\square$ Plasmodium spp. (-)

Figure 5 The level hemoglobin $(\mathrm{Hb})$ levels based on day of observation. The decrease in the level of hemoglobin in donor blood containing Plasmodium spp. compared to that of donor blood did not contain Plasmodium spp. was not significantly different ( $\mathrm{p}$ value $>0.05$ Independent $T$-test). However, statistical results showed that there was a significant difference in the $\mathrm{Hb}$ profile at the five-day observation ( $\mathrm{p}$ value $<0.000$, Friedman test and post-hoc Wilcoxon test) between the two groups. Different notations mean significant difference $(p<0.05)$.

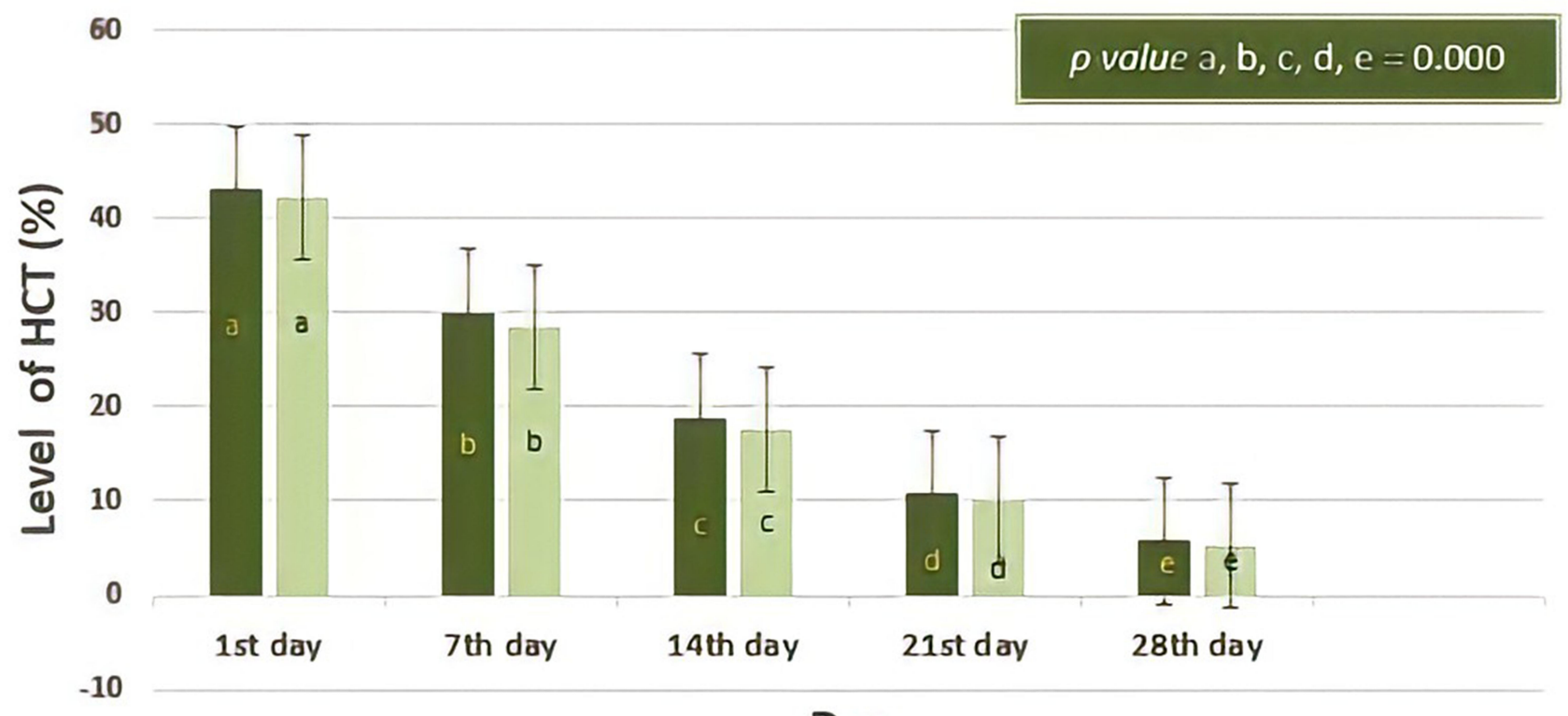

\section{Day}

Plasmodium spp. (+) @ Plasmodium spp. (-)

Figure 6 The percentage of Hematocrit (HCT) based on days of observation. Decreases in the percentage of hematocrit in donor blood containing Plasmodium spp. was not significantly different to those of donor blood that did not contain Plasmodium spp. ( $>>0.05$; Independent T-test). Among day observations, the level of hematocrit percentage were significantly different (all $p$ value $=0.000$, Repeated ANOVA test and post-hoc Paired Wise Comparison test) both in two groups. Different notations mean significant difference $(p<0.05)$. 


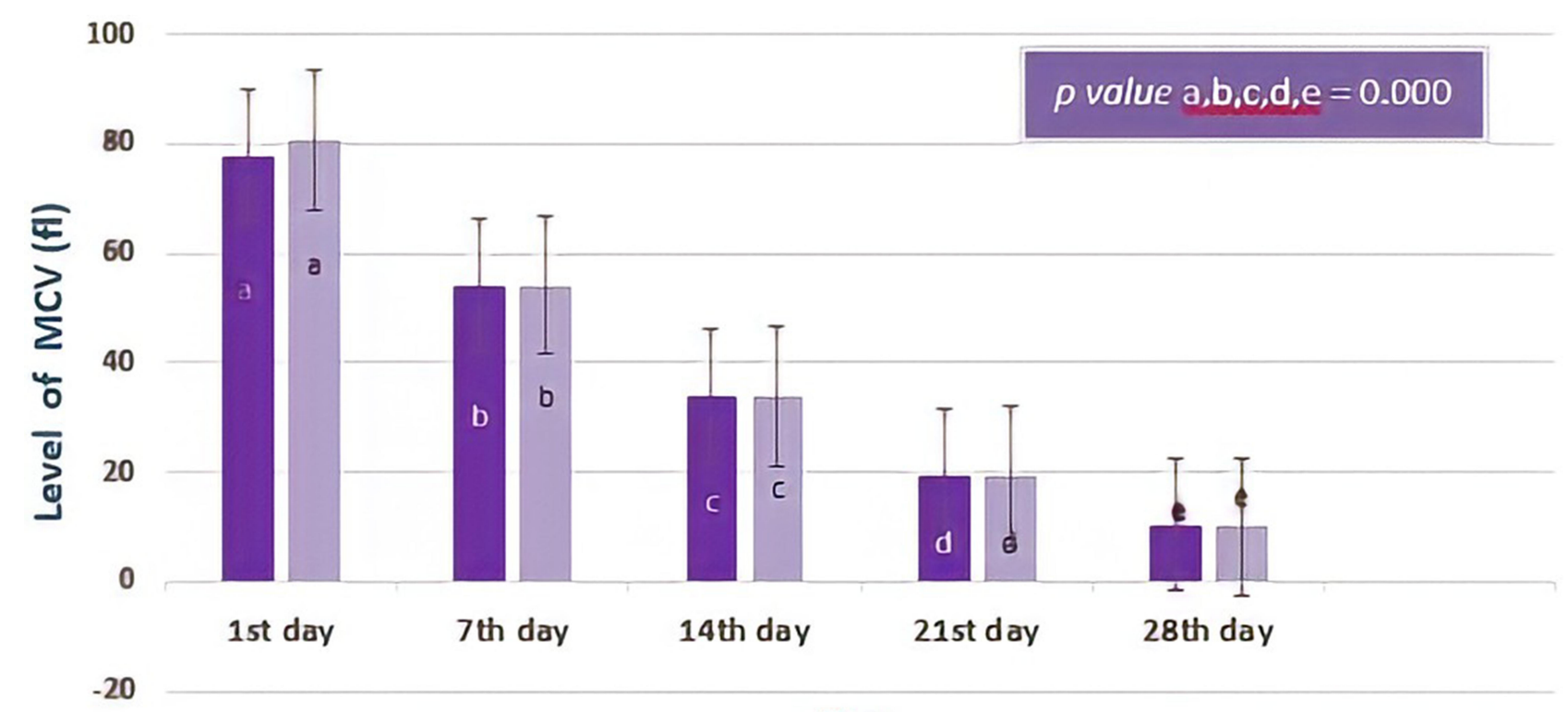

Day

- Plasmodium spp. (+) a Plasmodium spp. (-)

Figure 7 The level of Mean Corpuscular Volume (MCV) based on day of observation. The average level of MCV in donor blood containing Plasmodium spp. showed no significant difference compared to those in donor blood that did not contain Plasmodium spp. ( $>>0.05$; Mann-Whitney test). However, observation carried out from the first day to the twenty-eighth day of storage of level MCV showed a significant difference (all $\mathrm{p}$ value $=0.000$, Friedman test and post-hoc Wilcoxon test) both in two groups. Different notations mean significant difference $(p<0.05)$.

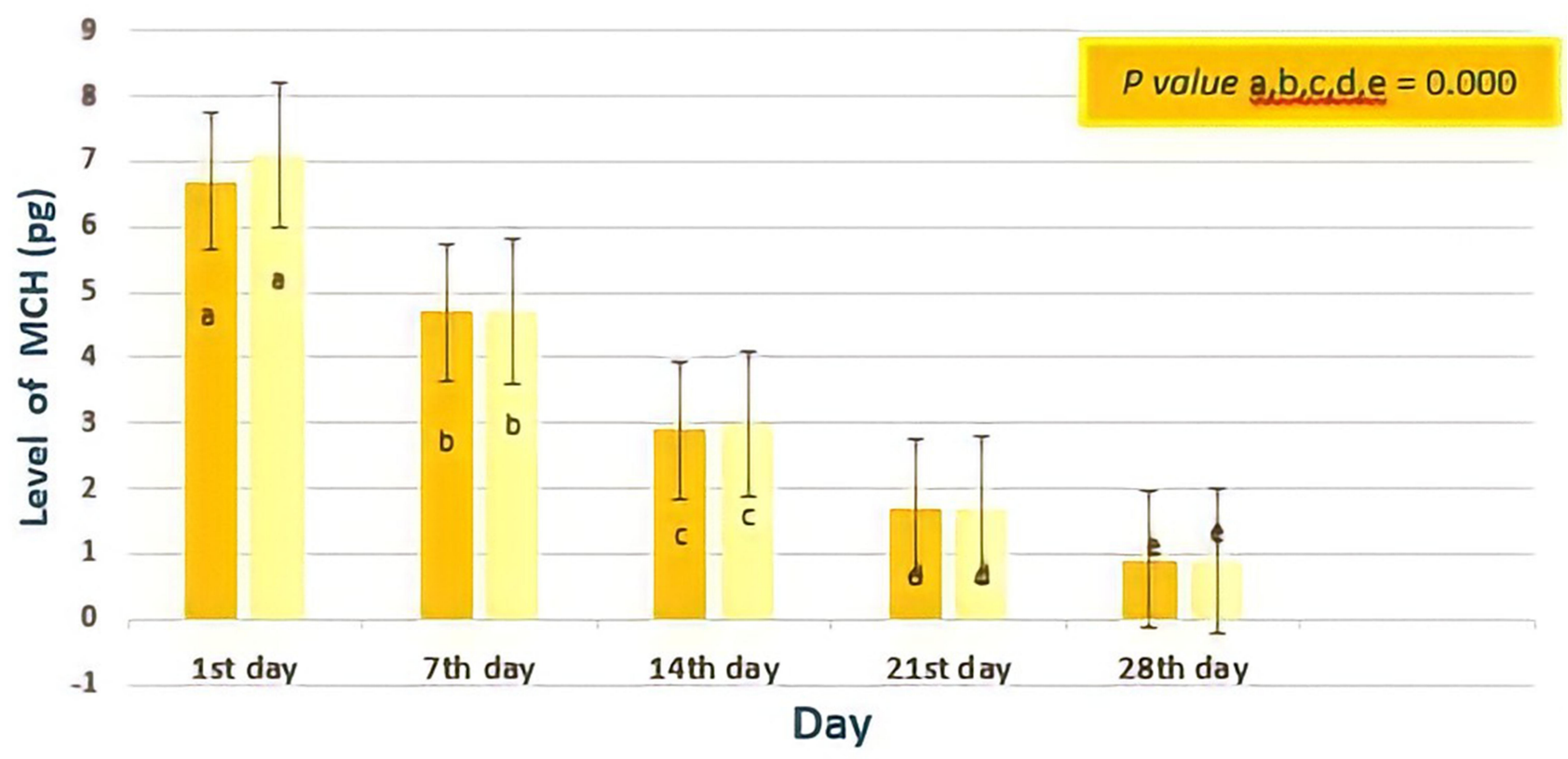

Plasmodium spp. (+) Plosmodium spp. (-)

Figure 8 The level of Mean Corpuscular Hemoglobin (MCH) based on days of observation. The MCH of erythrocytes from donor blood containing Plasmodium spp. and those did not containing Plasmodium spp. was not different (all P value $>0.05$; Independent T-test), but analysis on the level of $\mathrm{MCH}$ based on storage time showed a significant difference (all p value $<0.05$; Repeated ANOVA test and post-hoc Paired Wise Comparison test) both in two groups. Different notations mean significant difference $(p<0.05)$. 
Comparison test, there was a difference in the average level of $\mathrm{MCH}$ based on storage time (7th day lower than those at 1 st day, 14th day lower than those at 7 th day, 21 st day lower than those at 14th day, 28th day lower than those at 21st day).

The decrease of the MCHC levels from donor blood that did not contain Plasmodium spp. was not different from those in donor blood that contained Plasmodium spp. (Figure 9). However, in the twenty-first day to twentyeighth day examination, the decrease in the MCHC level of this group was very rapid, using Mann-Whitney test there were no significant differences in the results (the first day, $p=0.229$; seventh day, $p=0.477$; fourteenth day, $\mathrm{p}=0.548$; twenty-first day, $\mathrm{p}=0.449$; twenty-eighth day, $\mathrm{p}=0.499)$. Statistical analysis showed MCHC levels were different based on longer storage, 7 th day was lower than at 1 st day, 14th day was lower than the 7th day, 21st day was lower than the 14th day, 28th day was lower than the 21 st day (all $p$ value $=0.000$, Friedman test and post-hoc Wilcoxon test).

\section{Discussion}

Banjar Regency and Tanah Laut Regency are parts of malaria-endemic districts in South Kalimantan Province
(Routine Data from the Malaria Sub Directorate, Ministry of Health, Republic of Indonesia, 2017). ${ }^{8}$ However, malaria screening through microscopic examination and RDT has never been carried out during donor blood activities.

Donors who had a history of suffering from malaria but during donation activities showed no symptoms of malaria and met the criteria as a donor were allowed to donate blood. This might be the possible causes of malaria transmission through blood transfusions because although they felt healthy, their blood still had a risk to harbor Plasmodium parasites.

In this study, some of Plasmodium spp. was still found in RBCs until 14 days of storage. A Previous study revealed that cold storage of RBCs was able to support the growth of $P$. falciparum. The study also showed a decrease in the number of blood smear slides containing Plasmodium spp. during the sequential days of observation. It was assumed that the parasites have the capability to survive with minimal energy sources, such as in blood in the transfusion bags containing anticoagulant and stored at a certain temperature for many days. The limitation of cold storage environment might affect the parasite growth because some parasites are more likely to infect young RBCs. ${ }^{9}$ In the early days, Plasmodium in the blood may be

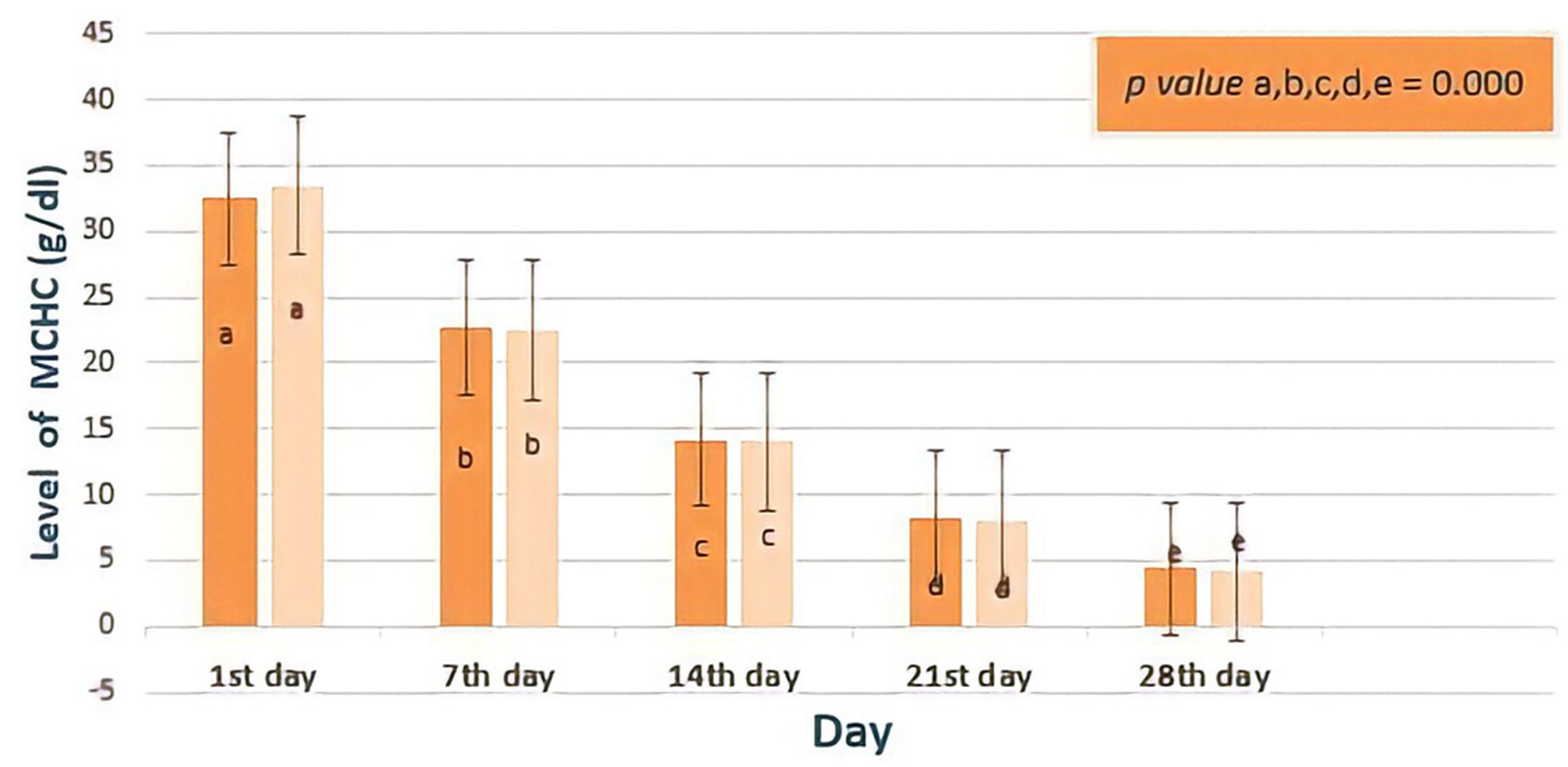

Plasmodium spp. (+) $\square$ Plasmodium spp. (-)

Figure 9 The levels of Mean Corpuscular Hemoglobin Concentration (MCHC) based on days of observation. There was no difference in the reduction of MCHC levels in donor blood containing Plasmodium spp. and those in donor blood that did not contain Plasmodiumspp. However, levels of MCHC based on storage time showed significant difference (all $p$ value $<0.05$, Repeated ANOVA test and post-hoc Wilcoxon test). Different notations mean significant difference $(p<0.05$ ). 
arrested for replication in terms of cold storage but after that, it was very likely it will die and disappear because of the microenvironment that did not support it. The survival mechanism of Plasmodium in infected donor blood during 14 days storage might be closely related to the regulation of the redox system by the Plasmodium through performing a new permeation pathway to obtain nutrient, antioxidant, and glucose from outside. However, it might be possible that Plasmodium is trying to maintain its viability in RBCs, a condition that later is suspected of potentially transmitting malaria. ${ }^{10}$

The profile of erythrocytes and the presence of parasites change starting at the first day of storage and decreased based on observation on the following day. Various factors cause a decrease in the level of erythrocyte profile parameters of the blood donor during storage times. According to Gregory et al, 2018, in addition to the decreased RBCs count, the leukocytes, the neutrophils, and lymphocytes count also decreased significantly $(\mathrm{p}<0.05)$. During storage, there will be biochemical changes, biomechanical damage and immunological reactions occur and cause hemolysis. ${ }^{11,12}$

Cooling stimulates the formation of sodium and the release of potassium so that there is a buildup of sodium and a decrease of potassium in RBCs. The mechanism of hemolysis begins with the metabolism of glucose into lactate with minimal energy sources, causing a decrease in the $\mathrm{pH}$. The RBCs surface becomes fragile and partially destroyed (lysis). The concentration of hemoglobin in the plasma increases while the Adenosine Tri Phosphate (ATP) concentration and 2,3 Diphosphoglycerides (2,3 DPG) levels decrease progressively. Erythrocytes (RBCs) lose their ability to synthesize amino acids and red blood cell fatty acids, ${ }^{13}$ hemoglobin $(\mathrm{Hb})$ is released directly into the liquid, causing the loss of lipid-containing micro-vesicles into the plasma, ${ }^{14}$ and making hemoglobin levels low. ${ }^{15}$ In fact, hemoglobin serves as the main source of nutrients in the form of amino acids for Plasmodium spp. in maintaining its survival, especially in hypotonic solutions. $^{16}$

Transfused blood storage is usually done for up to 35 days, depending on the anticoagulant used. ${ }^{4}$ According to observation in this study, we recommend donor blood is not feasible to be given to the recipient after the 21 st day of storage. However, a number of factors influence this event, including the storage temperature, the length of transportation (ie, when moving places from blood banks to laboratories), and the kind of anticoagulant.

During storage, ionized calcium levels increase causes blood to clot quickly. Anticoagulants in blood transfusions will slow the occurrence of storage lesions. The anticoagulant that is often used in transfusion is Citrate Phosphate Dextrose Adenine 1 (CPDA 1). The components in CPDA 1 (citrate, phosphate, dextrose, and adenine) are formulated to maintain the viability of blood cells and to minimize storage lesions that can happen because the mechanism of hemopoiesis does not occur outside the body. ${ }^{17,18}$

Citrate will work by inhibiting the activation of coagulation by binding to the calcium in the transfused blood, preventing cascade coagulation activation by inducing local hypocalcaemia. ${ }^{19,20}$ The calcium content of the donor most probably gives a part of the explanation for this interesting observation. It is thought that citrate functioned as an antioxidant, but in research by Erman et.al, (2016), citrate does not have a direct effect on oxidative stress. ${ }^{21}$ Citrate promotes and exacerbates the formation of ROS caused by the formation of hydrogen peroxide in cells. $^{22}$

Similarly, organic phosphate works by maintaining levels of 2,3 DPG so that the production of ATP as an energy source continues and blood cell viability is maintained, resulting in blood cell damage go slow. ${ }^{23}$ Dextrose is useful as an additional source of energy for blood cells during storage, which allows RBCs to be able to carry out glycolysis so that ATP is produced. Glycolysis can be slowed down by storing transfused blood at temperatures of $2-4^{\circ} \mathrm{C}$, while adenine will save the use of other substrates needed during ATP synthesis. ${ }^{19}$ The buffer function in anticoagulants can overcome the decrease in hydrogen levels due to temperatures that are too cold so that the $\mathrm{pH}$ is maintained. ${ }^{24,25}$

In blood donors, whole blood and plasma, when stored at $-4^{\circ} \mathrm{C}$, Plasmodium spp. was found to survive up to 18 days, and detectable parasites can present even up to 28 days when frozen. ${ }^{16}$ This study has shown the RBCs count from donor blood both containing or did not contain Plasmodium spp. decreased on the first day until the 21 st day of examination and was not a significant difference between them in all day observation. This shows that there is damage to RBCs that immediately occur when outside the blood vessels. These changes result in hemolysis resulting in nitric oxide [NO] reduced bioactivity due to scavenging, morphological changes, accumulation of lactic acid and potassium/calcium, a decrease in 2,3-DPG 
and ATP, decrease in $\mathrm{pH}$ and glycolysis rate, and an accumulation of shed bioactive proteins, lipids, and RBCderived micro-particles or micro-vesicles. ${ }^{26}$ Anticoagulants and storing in hypothermic conditions are expected to slow down cell metabolism, so biochemical reactions and accumulation of the remaining metabolism do not cause blood cell death. It is suspected that Plasmodium spp. maintains its host cell (RBCs) so that it does not quickly damage (lysis) ${ }^{27}$ possibly by regulating its redox system.

Unlike the case with RBCs that are not infected with Plasmodium spp. oxidative stress in infected RBCs increases when outside the lumen of the blood vessels resulting in their eventual damage by hemolysis. ${ }^{28}$ However, the infected RBCs increase more in their permeability to obtain substantial low-molecular-weight solutes (glucose, anti-oxidant compared to the uninfected erythrocyte. ${ }^{29,30}$ The forming of new permeation pathways (NPP), an increase in permeability can be attributed to a single type of permeation pathway with characteristics quite distinct from those of the host. ${ }^{31,32}$ A channel on the parasitophorous vacuole membrane (PVM) has been described $^{33,34}$ and projections from the PVM, called the tubulo-vesicular membrane network (TVM), have been implicated in the acquisition of nutrients. ${ }^{34,35}$ These mechanisms proposed a direct connection of the Plasmodium spp. to the plasma during prolonged storage.

Erythrocyte (RBCs) contains a conjugate protein derived from hemoglobin. The main function of hemoglobin is to bind and release oxygen and carbon dioxide. Plasmodium spp. in the intraerythrocytic stage will digest the host cell cytosol which has a large amount of hemoglobin. This hemoglobin is the main generator of ROS. ${ }^{25}$ The functional role of red blood cells (RBCs) is the transport of oxygen from the lungs to the tissues providing the oxygen required by all cells and tissues. Hemoglobin $(\mathrm{Hb})$ accounts for $95-97 \%$ of the cytosolic proteins inside the $\mathrm{RBC}$, and bind to oxygen reversibly. Extracellular hemoglobin can be a major source of oxidative stress. Under normal conditions, this potential source of oxidative stress is minimized by haptoglobin and hemopexin, which bind $\mathrm{Hb}$ and free heme, respectively. They inhibit the oxidative reactions of $\mathrm{Hb}$ and heme and facilitate their removal from circulation. Elevated levels of free extracellular $\mathrm{Hb}$ and heme are caused by the failure of neutralized reaction by hap- to globin and hemopexin. ${ }^{36}$

Hemoglobin is a source of energy for Plasmodium spp., whereas as long as blood transfusions are stored, there is no formation of hemoglobin even though anticoagulants have been given. Hemolysis that occurs during storage causes the release of hemoglobin directly into the liquid through lipid-containing micro-vesicles, resulting in lost hemoglobin from intact RBCs entering the plasma supernatant. ${ }^{26}$ In this study, hemoglobin levels from transfused blood containing Plasmodium spp. decreased from the first day, although the results of data analysis did not show differences between hemoglobin levels from transfused blood containing Plasmodium spp. and those from transfused blood that did not contain Plasmodium spp.

Hematocrit is the ratio of the number of RBCs to blood volume in percent units that shows the density of the blood with the amount of oxygen it carries. A decrease in hematocrit levels indicates that the invasion and rupture of red blood cells are more influential than the hemoglobin value as indicated by an increase in MCHC levels. ${ }^{37}$ The results showed that there was a significant difference between the storage time and blood temperature of the donors on the hematocrit levels, although there was no significant difference between the hematocrit levels in the blood of infected and non-infected donors.

From the data of Figures 7-9, it could be assumed that there was a change of osmotic fragility of RBCs from transfused blood containing Plasmodium spp. and that which did not contain Plasmodium spp. Osmotic fragility begins with changes in the size of RBCs which can be seen from the erythrocyte index, containing MCV levels, $\mathrm{MCH}$ levels, and MCHC levels. ${ }^{38-42}$ This shows that RBCs damage starts from the ability of the RBCs membrane and its ligands. Blood cells that come out of the vascular system and undergo the storage process release phospholipids from the hematocrit RBCs, and cause osmotic damage to form schistocytes and speroecinocytes. Finally, most RBCs are increased osmotic fragility. ${ }^{38-40}$

This study requires further exploration to see the effect of Plasmodium invasion on the viability of red blood cells or vice versa. From this study, it was suspected that there was a Plasmodium defense mechanism to keep the survival of erythrocyte through redox balance. A research using Plasmodium subculture method and analyzing of redox status in infected erythrocytes would answer the question about both the mechanism of erythrocytes and parasite viability during transfusion storage.

\section{Conclusions}

From this study, there is no significant difference in the profiles of erythrocytes between donor blood that is infected 
by Plasmodium spp. and that which is not infected. This observational study showed that there were trends in significantly reducing all parameters of erythrocyte profile in the bags of donor blood relevant to the duration of storage, as well as the presence of malaria parasites in the blood. The transfusion transmission of the malaria parasite will still potentially occur as long as the erythrocytes are still viable.

\section{Abbreviations}

2,3 DPG, 2,3 Diphosphoglycerides; AIDS, Acquired Immune Deficiency Syndrome; ATP, Adenosine Tri Phosphate; CPDA 1, Citrate Phosphate Dextrose Adenine 1; Hb, Hemoglobin; HIV, Human Immunodeficiency Virus; HCT, Hematocrit; MCV, Mean Corpuscular Volume; MCH, Mean Corpuscular Hemoglobin; MCHC, Mean Corpuscular Hemoglobin Concentration; NO, nitric oxide; PVM, parasitophorous vacuole membrane; RDT, Rapid Diagnostic Test; PCR, Polymerase Chain Reaction; ROS, Reactive oxidant species; RBCs, Red Blood Cells; TTM, Transfusion Transmitted Malaria; TVM, tubulovesicular membrane network; VDRL, Venereal Disease Research Laboratory; WHO, World Health Organization.

\section{Acknowledgments}

We would like to forward our appreciation to Blood Bank Banjar and Tanah Laut District South Kalimantan Indonesia, Public Health Office Banjar and Tanah Laut District South Kalimantan Indonesia, and Ministry of Research and Technology Republic of Indonesia for financial and material supports of the research.

\section{Author Contributions}

All authors made a significant contribution to the work reported, whether that is in the conception, study design, execution, acquisition of data, analysis and interpretation, or in all these areas; took part in drafting, revising or critically reviewing the article; gave final approval of the version to be published; have agreed on the journal to which the article has been submitted; and agree to be accountable for all aspects of the work.

\section{Funding}

This study is supported by the Ministry of Research and Technology Republic of Indonesia.

\section{Disclosure}

The authors declare that they have no conflict of interests for this work.

\section{References}

1. Getaneh A, Mohammedaman M. Asymptomatic malaria infection and associated factors among blood donors attending Arba Minch blood bank, Southwest Ethiopia. Ethiop J Health Sci. 2017;28 (3):315-335. doi:10.4314/ejhs.v28i3.9

2. O'Brien SF, Delage G, Seed CR, et al. The epidemiology of imported malaria and transfusion policy in 5 non-endemic countries. Transfus Med Rev. 2015;29(3):162-171. doi:10.1016/j.tmrv.2015.03.004

3. Indonesian Government Regulation No.7 of 2011 about Blood Services

4. Queen E, Ifeanyi OE, Chinedum OK. The effect of storage on full blood count in different anticoagulants. IOSR J Dental Med Sci. 2014;13(9):128-131.

5. Antonelou MH, Kriebardis AG, Stamoulis KE, Economou-Petersen E, Margaritis LH, Papassideri IS. Red blood cell aging markers during storage in citrate-phosphate-dextrose-saline-adenine-glucose-mannitol. Transfusion. 2010;50(2):376-389. doi:10.1111/j.1537-2995.2009.02449

6. Paul AS, Egan ES, Duraisingh MT. Host-parasite interactions that guide red blood cell invasion by malaria parasites. Curr Opin Hematol. 2015;22:220-226.

7. Nubila T, Ukaejiofo EO, Nubila NI, et al. Hematological profile of apparently healthy blood donors at a tertiary hospital in Enugu, southeast Nigeria: a pilot study. Niger $J$ Exp Clin Biosci. 2014;2:33-36.

8. Kementerian Kesehatan Republik Indonesia. Pertemuan Monitoring Dan Evaluasi Eliminasi. Subdit Malaria - Ditjen: P2P; 2017.

9. Sons JW. Bio-preservation of RBCs for in vitro Plasmodium falciparum culture. Br J Haematol. 2016;175(4):733-747. doi:10.1111/ bjh. 13882

10. Chattopadhyay R, Majam VF, Kumar S. Survival of Plasmodium falciparum in human blood during refrigeration. Transfusion. 2011;51:630-635.

11. Gregory B, Dan A, Leonid L, Alexander G. Is it possible to reverse the storage-induced lesion of red blood cells? Front Physiol. 2018;9:914. doi:10.3389/fphys.2018.00914

12. Remy KE, Sun J, Wang D, et al. Transfusion of recently donated (fresh) red blood cells (RBCs) does not improve survival in comparison with current practice, while safety of the oldest stored units is yet to be established: a meta-analysis. Vox Sang. 2016;111(1):43-54. doi:10.1002/14651858.CD009330.pub2

13. Pawan KM, Prabhanshu K, Pranjal C. Biomarkers of oxidative stress in erythrocytes as a function of human age. World J Methodol. 2015;5 (4):216-222. doi:10.5662/wjm.v5.i4.216

14. Francesca R. The potential adverse effects of hemolysis. Blood Transfus. 2017;15(3):218-221.

15. Marion K, Jake B. The mechanics of malaria parasite invasion of the human erythrocyte - towards a reassessment of the host cell contribution. Cell Microbiol. 2016;18(3):319-329.

16. Antwi-Baffour S, Adjei JK, Agyemang-Yeboah F, et al. Proteomic analysis of micro-particles isolated from malaria positive blood samples. Proteome Sci. 2016;15:5.

17. Cora MC, King D, Betz LJ, Wilson R, Travios GS. Art factual changes in Sprague-Dawley Rat hematologic parameters after storage of samples at $3^{\circ} \mathrm{C}$ and $21^{\circ} \mathrm{C}$. Am Assoc Lab Anim Sci. 2012;51 (5):616-621.

18. Lindstrom NM, Moore DM, Zimmerman K, Smith SA. Hematologic assessment in pet rats, mice, hamsters, and gerbils: blood sample collection and blood cell identification. Vet Clin North Am Exot Anim Pract. 2015;18(1):21-32.

19. Kissling S, Legallais C, Pruijm M, et al. A new prescription model for regional citrate anticoagulation in therapeutic plasma exchanges. BMJ Nephrol. 2017;18(1):81. doi:10.1186/s12882-017-0494-9

20. Verma M, Dahiya K, Malik M, Sehgal PK, Devi R. Soni A and Ghalaut VG. Effect of blood storage on complete biochemistry. J Blood Disord Transfus. 2015;6:6. doi:10.4172/2155-9864.1000359 
21. Erman H, Aksu U, Belce A, et al. Aydın S and Çakatay U. Gender and chronological age affect erythrocyte membrane oxidative indices in citrate phosphate dextrose adenine-formula 1 (CPDA-1) blood bank storage condition. Gen Physiol Biophys. 2016;35:343-351. doi:10.4149/gpb_2016001

22. Rahbari M, Diederich K, Becker K, Krauth-Siegel RL, Jortzik E. Detection of thiol-based redox switch processes in parasites-Facts and future. Biol Chem. 2015;396(5):445-463. doi:10.1515/hsz-20140279

23. Amna MA, Sven CV, Afnan SA, et al. Whole blood storage in CPDA1 blood bag alters erythrocyte membrane proteome. Oxid Med Cell Longev. 2018;1-12. doi:10.1155/2018/6375379

24. Tatsuro Y, Michel P, Angelo D. Red blood cell storage lesion: causes and potential clinical consequences. Blood Transfus. 2019;17 (1):26-52. doi:10.2450/2019.0217-18

25. Flatt JV, Bawazir WM, Bruce LJ. The involvement of cation leaks in the storage lesion of red blood cell. Front Physiol. 2014;214(5):1-10. doi:10.3389/fphys.2014.00214

26. Joseph MR, Joy GM, Enika N. The pathophysiology of extracellular hemoglobin associated with enhanced oxidative reactions. Front Physiol. 2015;5:500. doi:10.3389/fphys.2014.00500

27. Birgit V, Thibault G, Don AL, et al. In silico mining for antimalarial structure-activity knowledge and discovery of novel antimalarial curcuminoids. Molecules. 2016;21(7):853. doi:10.3390/molecules 21070853

28. Sparrow RL. Time to revisit red blood cell additive solutions and storage conditions a role for "omics" analyses. Blood Transfus. 2012;10(Supp12):s7-s11. doi:10.2450/2012.003S

29. Ginsburg H, Atamna H. The redox status of malaria-infected erythrocytes: an overview with an emphasis on unresolved Problems. 1997;1 (1):5-13.

30. Egée S, Bouyer G, Thomas SLY. Permeabilization of host cell membrane. Encyclopedia Malaria. 2015;1-14. doi:10.1007/9781-4614-8757-9 38-1

31. Kirk K. Channels and transporters as drug targets in the Plasmodium-infected erythrocyte. Acta Trop. 2004;89:285-298.

32. Dickerman BK, Elsworth B, Cobbold SA, et al. Identification of inhibitors that dually target the new permeability pathway and dihydroorotate dehydrogenase in the blood stage of Plasmodium falciparum. Sci Rep. 2016;6:37502. doi:10.1038/srep37502
33. Adamu J, Jigam AA. Effects of malaria infection on some haematological and biochemical parameters in the general population and pregnant malaria patients attending two district hospitals in Niger State, Nigeria. Glob J Infect Dis Clin Res. 2019.

34. Desai SA, Krogstad DJ, McCleskey EW. A nutrient-permeable channel on the intraerythrocytic malaria parasite. Nature. 1993;362: 643-645.

35. Goldberg DE, Zimmerberg J. Hardly Vacuous: the Parasitophorous Vacuolar Membrane of Malaria Parasites. Trends Parasitol. 2020;36.2:138-146. doi:10.1016/j.pt.2019.11.006

36. Kanti BP, Syed IR. Biomarkers of oxidative stress in red blood cells. Biomed Pap Med Fac Univ Palacky Olomouc Czech Repub. 2011;155(2):131-136.

37. Lauer SA, Rathod PK, Ghori N, Haidar K. A membrane network for nutrient import in red cells infected with the malaria parasite. Science. 1997;1122-1125.

38. María G, María C, Vicente-Ayuso AMB, et al. Red blood cell storage time and transfusion: current practice, concerns and future perspectives. Blood Transfus. 2017;15(3):222-231. doi:10.2450/ 2017.0345-16

39. Canavese M, Spaccapelo R. Protective or pathogenic effect of vascular endothelial growth factor (VEGF) as potential biomarker in cerebral malaria. Pathog Glob Health. 2014;108(2):67-75. doi:10.1179/2047773214Y.0000000130

40. Dunst J, Kamena F, Matuscewski K. Cytokine and chemokine in cerebral malaria pathogenesis. Front Cell Infect Microbiol. 2017;7:324.

41. Chaudhary R, Katharia R. Oxidative injury as contributory factor for red cells storage lesion during twenty eight days os storage. Blood Transfus. 2012;10(1):59-62. doi:10.2450/2011.0107-10

42. Keohane EM. Intrinsic Defects Leading to Increased Erythrocyte Destruction. In: Keohane EM, Smith LJ, Walenga JM, editors. Rodak's Hematology: Clinical Principles and Applications. 5th ed. Missouri: Elsevier Saunders; 2016:367-389.
Journal of Blood Medicine

\section{Publish your work in this journal}

The Journal of Blood Medicine is an international, peer-reviewed open access, online journal publishing laboratory, experimental and clinical aspects of all aspect pertaining to blood based medicine including but not limited to: Transfusion Medicine; Blood collection, Donor issues, Transmittable diseases, and Blood banking logistics; Immunohematology; Artificial and alternative blood based therapeutics; Hematology; Biotechnology/nanotechnology of blood related medicine; Legal aspects of blood medicine; Historical perspectives. The manuscript management system is completely online and includes a very quick and fair peer-review system. Visit http://www.dovepress.com/testimonials.php to read real quotes from published authors. 